\title{
Beneficial effects of ton-bag and wire-steel pallet on postharvest handling of onion and the cost evaluation
}

\author{
Young-Deuk Kwon* \\ Korea Pool Network Co., Ltd., Seoul 04157, Korea
}

\section{톤백 및 와이어철제파렛트 이용에 따른 양파의 수확후관리 효율성 증대와 경제성 평가}

\author{
권영득* \\ (주)한국풀네트웍
}

\begin{abstract}
This study aimed in onion production by evaluating cost and labor efficiencies of onion storage methods using either a ton-bag or a wire-steel pallet. New methods using ton-bag and wire-steel pallets were developed and applied to postharvest tasks, such as harvest packaging, transportation, and storage. The storage parameters evaluated for their effect on the logistics of onion production were: working duration, working hours, and cost expenditure. The longitudinal tensile strength of the ton-bag developed in this study was $16 \%$ higher than that of the conventional ton-bag. The wire-steel pallet developed in this study had $10 \%$ more storage capacity in a low-temperature storage room, and its truck loading capacity was more than doubled compared to that of the conventional steel pallet. There was no difference in the wasting rate during bulk storage between the newly developed wire-steel pallet and the conventional steel pallet, for $500 \mathrm{~kg}$ of onions. However, the bulk storage of $1,000 \mathrm{~kg}$ of onions using the wire-steel pallet was not found to be suitable, because the wasting rate of onions stored using the wire-pallet was 3.7\% higher than that of onions stored using a conventional steel pallet. The time and the total investing costs for the bulk method decreased by $\mathbf{5 0 . 1 \%}$ and $\mathbf{4 6 . 1 \%}$, respectively, compared to those for conventional harvest. In the bulk storage using the wire-steel pallet, the total storage cost decreased by $28.8 \%$. Thus, it is estimated that we could have saved 18.3 billion won if the wire-steel pallet method about $30 \%$ of the total onion production $(1,298,749 \mathrm{M} / \mathrm{T})$ in 2016.
\end{abstract}

Key words : bulk, economic efficiency, harvest, mechanized, logistics

\section{서 론}

우리나라 양파 재배면적은 2016년 기준으로 전남이 $48.1 \%$ 로 재배면적이 가장 많았으며 경남은 $24.0 \%$ 그리고 경북은 $11.4 \%$ 로 전체 양파 재배면적의 약 $83.5 \%$ 를 차지할 정도로 주산지 집중도가 높은 작물이다(1). 양파는 수확

*Corresponding author. E-mail : kyd5574@hanmail.net Phone : 82-2-2038-7236, Fax : 82-2-3669-7797

Received 10 October 2017; Revised 10 November 2017; Accepted 20 November 2017.

Copyright (c) The Korean Society of Food Preservation. All rights reserved.
시 $20 \mathrm{~kg}$ 그물망을 사용하여 포장, 운반, 하역, 저장 그리고 출하하고 있으며, 이런 관행 수확 작업은 산지 물류하역의 과도한 인력이 투입되어야 하며 저온저장 이후에도 부패된 양파를 선별하기 위해서 그물망을 해체하여 선별 후 재포장 하는 비효율적인 작업을 하고 있는 실정이다(2). 양파의 생산비는 지속적으로 증가하고 있는 추세이며 특히 총생산 비의 약 $45 \%$ 를 차지하는 노동비의 부담이 점차 가중되고 있다(3). 양파 재배에 있어서 수확작업이 이루어지는 5월-6 월과 정식작업이 이루어지는 10 월 하순-11월 중순)은 가장 많은 노동력이 투입되고 있는데 인력수확은 $10 \mathrm{a}$ 당 16.8 시 간이 필요하지만 기계수확은 3.8 시간으로 13 시간의 절감 효과가 있는 것으로 나타났다(4). 양파 수확은 대부분 20 
$\mathrm{kg}$ 그물망을 이용하며 일부 농가에서 플라스틱 박스나 톤 백을 이용하고 있다. $20 \mathrm{~kg}$ 그물망은 취급과정에서 양파의 물리적 손상이 크며 파렛트에 의한 다단적재가 불가능하고 하역기계화가 어려운 단점이 있다. 플라스틱 상자 수확은 압상에 의한 물리적 손상을 줄일 수 있는 장점이 있지만 초기 투자비용이 많이 들고 사용중 파손과 분실 등으로 유지 및 보수비용이 많이 드는 단점이 있다. 톤백 수확은 기계수확 및 하역 작업에 유리하지만 양파 저장시 파렛트와 조합하여 사용해야 하며 견고성과 통기성이 취약한 단점이 있다. 양파 저장방식은 주로 $20 \mathrm{~kg}$ 그물망을 철제파렛트에 적재하여 저장하는데 철제파렛트 1 개당 $20 \mathrm{~kg}$ 그물망을 $50-70$ 망 적재하고 압상 방지를 위해 2단으로 층을 분리해서 사용하고 있다. 기존에 사용하고 있는 철제파렛트는 무겁 고, 산지에서는 비규격의 고정형 철제파렛트를 사용하여 이동 및 보관시 물류효율이 떨어지며 사용 종료 후 보관 장소가 필요하다는 단점이 있다. 또한 최근에 건설되는 저 온저장고의 대부분은 표준파렛트 규격을 기준으로 적재방 법을 감안하여 시설규격을 정하기 때문에 표준파렛트 규격 을 참고하여 새로운 물류기기를 도입해야 한다. 이에 새로 개발하는 접철식 와이어철제파렛트는 국가표준사이즈로 물류효율성, 보관 및 이동 보관 시 접철방식으로 많은 수량 을 이동시킬 수 있으며, 산지에서 요구하는 다양한 규격으 로 개발이 가능하다.

이렇게 양파 생산비 절감을 위해 노동비의 대부분을 차 지하고 있는 수확작업의 저비용 및 고효율화를 위해서는 기존에 $20 \mathrm{~kg}$ 그물망을 사용하지 않는 수확용 톤백 및 벌크 저장용 철제파렛트의 개발이 필요하다. 따라서 본 연구는 양파의 수확 시 재배지에서 벌크상태로 수확하여 수송, 하 역 그리고 보관 및 저장할 수 있도록 톤백 및 와이어철제파 렛트를 개발한 후 관행저장 방식과 벌크저장 후 저장성을 비교하고 그에 따른 노동투입시간 및 소요비용을 평가하여 양파의 산지물류비 절감 효과를 비교 분석하고자 수행하였 다.

\section{재료 및 방법}

\section{톤백 개발}

톤백은 Fig. 1 과 같이 크기는 $900 \times 900 \times 1,100 \mathrm{~mm}(\mathrm{~L} \times \mathrm{W}$ $\times \mathrm{H})$ 로 제작하였다. 톤백 제작에 사용된 원단의 재질은 폴리 프로필렌(PP)으로 1,500 denier $14 \times 14 /$ sq.inch이고 중량은 $191 \mathrm{~g} / \mathrm{sq} . \mathrm{m}$ 이며, 망사 재질은 폴리에틸렌(PE)로 중량은 188 $\mathrm{g} / \mathrm{sq} . \mathrm{m}$ 을 사용하였다. 이때 섬유 굴기를 나타내는 단위인 denier는 단위중량 $0.05 \mathrm{~g}$ 을 표준길이 $450 \mathrm{~m}$ 로 뽑는 것을 1 unit이다. 또한 톤백 상부는 지게차의 포크로 사방에서 적입이 가능한 구조인 로프타입으로 제작하였다.

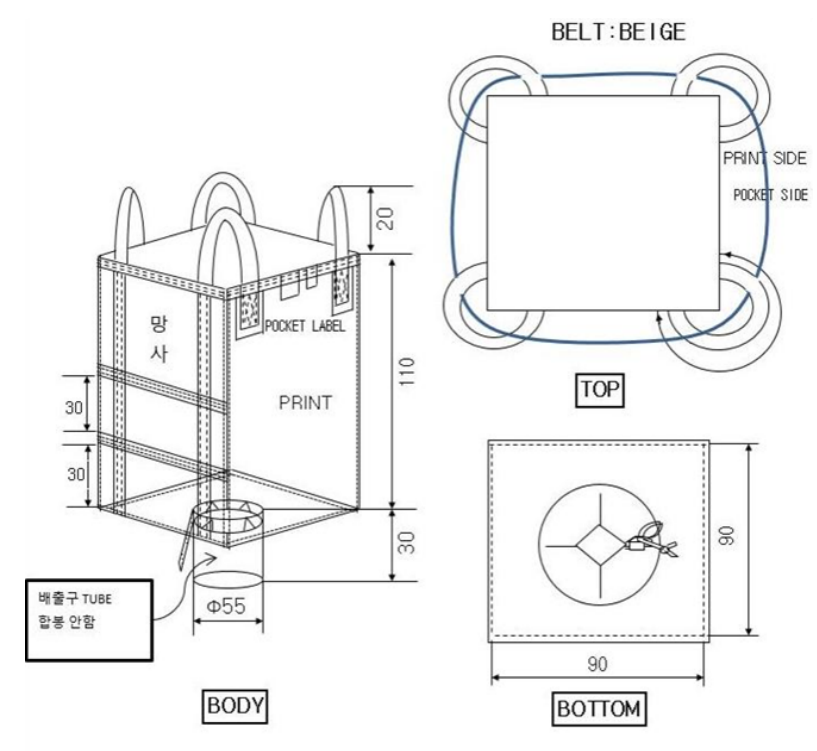

BODY:TUBULAR

Fig. 1. The drawing of development of ton-bag for bulk harvest. The drawing of new developed rope-type ton bag for bulk handling at harvest of onion (unit: $\mathrm{cm}$ ).

\section{접철식 와이어철제파렛트 개발}

와이어철제파렛트는 Fig. 2와 같이 제작하였으며, 규격 은 3 가지로 제작하였다. 와이어의 굵기는 $6 \mathrm{~mm}$ 이며 메쉬의 간격은 $50 \times 50 \mathrm{~mm}$ 으로 제작하였다. 와이어철제파렛트의 하부는 사방에서 지게차 작업이 가능한 형태로 제작하였으 면 다단적재와 접철이 가능한 접철식으로 제작하였다. 개 발된 와이어철제파렛트는 구조해석프로그램인 'ANSYS' 프로그램을 이용하여 압력이 가중되었을 때 와이어철제파 렛트의 구조적 변형 가능성을 검토하여 제작하였다.
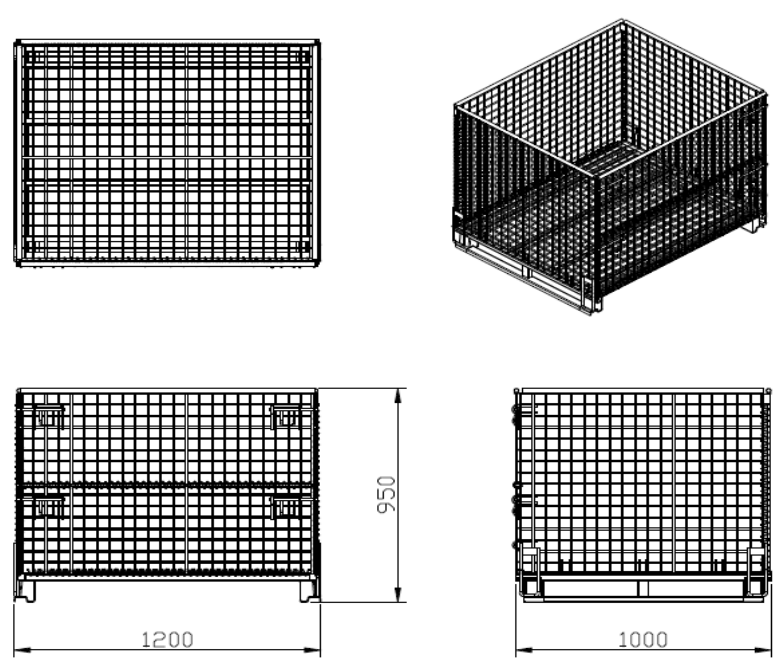

Fig. 2. The drawing of new developed wire-steel pallet for bulk storage of onion (unit: $\mathrm{mm}$ ). 


\section{공시재료 및 저장조건}

양파의 적정 저장 조건에서 온도는 $0^{\circ} \mathrm{C}$ 전후 그리고 상대 습도는 70-80\%가 적당한 것으로 보고되어 있다(5). 본 실험 에서는 전남 $\mathrm{A}$ 업체, 경북 $\mathrm{B}$ 업체, 경남 $\mathrm{C}$ 업체, 전북 $\mathrm{D}$ 업체 등 4곳을 실험 저장업체로 선정하였다. 양파 저장실험 중 저온저장고 온도는 저장 후 1 개월 이후부터 온도는 $0-0.5^{\circ} \mathrm{C}$ 를 상대습도는 70-80\%를 유지하도록 설정하였으며 동일한 저온저장고에 와이어철제파렛트를 이용한 벌크저장과 관 행 $20 \mathrm{~kg}$ 그물망을 넣은 철제파렛트를 동시에 적입하여 두 차례(2015년, 2016년)에 걸쳐 각각 감모율을 조사하였 다. 현장 실증실험 조건은 저장기간, 저장물량, 파렛트 크기 그리고 품종 등을 산지별 상황에 따라 조정하여 설정하였 다.

전남 무안군 현경면 소재 밭에서 2014년 11월 3일 정식하 고 2015년 6월 11일 수확한 양파는 ‘카타마루' 품종이며, 2015년 6월 17일 A업체 산지유통센터에서 적입하였다. A 업체에 사용한 와이어철제파렛트는 $1,200 \times 1,000 \times 950 \mathrm{~mm}$ 규격으로 평균 $483 \mathrm{~kg}$ 의 양파가 적재되어 저장되었다. 경북 문경시 영순면 소재 밭에서 2014년 11월 1일 정식하고 2015 년 6월 16일 수확한 양파는 '뉴마르스' 품종이며, 2015년 6월 23일 $\mathrm{B}$ 업체 산지유통센터에서 적입하였다. $\mathrm{B}$ 업체에 사용한 와이어철제파렛트 규격은 $1,100 \times 1,100 \times 1,100 \mathrm{~mm}$ 으로 평균 $575 \mathrm{~kg}$ 의 양파가 적재되어 저장되었다. 경남 함 양군 함양읍 소재 밭에서 2014년 11월 2일 정식하고 2015년 6월 8일 수확한 양파는 '썬파워' 품종이며, 2015년 6월 12일 $\mathrm{C}$ 업체 산지유통센터에서 적입하였다. $\mathrm{C}$ 업체에서 사용한 와이어철제파렛트는 $1,600 \times 1,000 \times 1,300 \mathrm{~mm}$ 규격으로 평 균 $835 \mathrm{~kg}$ 의 양파가 적재되어 저장되었다.

2 년차 저장실험은 전남의 $\mathrm{A}$ 업체와 전북의 $\mathrm{D}$ 업체에서 진행하였다. 전남 무안군 현경면 소재 밭에서 2015년 11월 1일 정식하고 2016년 6월 8일 수확한 양파는 '파워볼' 품종 이며, 2016년 6월 15일 $\mathrm{A}$ 업체 산지유통센터에서 적입하였 다. $\mathrm{A}$ 업체에서 사용한 와이어철제파렛트는 $1,200 \times 1,000$ $\times 950 \mathrm{~mm}$ 규격으로 평균 $483 \mathrm{~kg} / \mathrm{ea}$ 의 양파가 적재되어 저장 되었다. 전북 완주군 고산면 소재 밭에서 2015년 11월 2일 정식하고 2016년 6월 12일 수확한 양파는 '만다라' 품종이 며, 2016년 6월 17일 $\mathrm{D}$ 업체 산지유통센터에서 적입하였다.
$\mathrm{D}$ 업체에서 사용한 와이어철제파렛트는 $1,200 \times 1,000 \times 950$ $\mathrm{mm}$ 규격으로 파렛트당 평균 $460 \mathrm{~kg}$ 의 양파를 적재되어 저장되었다. 각 벌크저장 실험에서 대조구는 동일 품종의 양파를 망으로 수확하여 기존 철제파렛트에 적재하여 동일 한 조건의 창고에 저장하여 감모율을 비교하였다(Table 1).

\section{저장감모율}

본 실험에서 양파의 $20 \mathrm{~kg}$ 관행 그물망 저장방법과 와이 어철제파렛트의 벌크저장방법의 실제적인 감모율을 분석 하였다. 부패율을 포함한 총감모율을 구하는 방법은 아래 와 같다.

$$
\text { 감모율 }(\%)=\frac{\text { 입고 전 원물무게-저장 후 상품 출하 무게 }}{\text { 저장저온저장고 입고 전 원물무게 }} \times 100
$$

양파의 저장유형별로 감모율의 표본평균 사이에 차이가 존재하는지 확인하기 위해 $\mathrm{t}$-검정을 실시하였다. 가설검정 에 앞서 두 저장유형의 감모율 분산이 동일한지 여부인 동분산 검정을 실시한 후 감모율 평균의 동일성에 대한 t-검정을 SAS의 't-test 프로시저'를 이용하여 수행하였다.

\section{양파 수확 및 저장의 경제성 분석}

경제성 분석을 위한 투입비용에는 양파 생산지에 소재한 농협 및 농가에서 $20 \mathrm{~kg}$ 그물망 관행수확 및 벌크수확에 따른 인건비와 투입인원 등에 대한 자료조사가 포함되었 다. 양파재배에서 육묘, 정식, 재배, 자르기 그리고 뽑기까 지의 공정에 소요되는 투입노동시간과 투입비용은 동일하 다고 봤을 때, 그 이후 진행 공정은 담기, 상차, 수송, 하차, 적재 그리고 저장에 대해서 투입노동력 및 투입비용을 조사 항목으로 설정하였다.

관행방법과 벌크장법에 따른 노동시간과 투입비용은 양 파 주산지인 경남, 경북, 전남, 전북지역의 대표적인 산지농 협과 영농조합 및 농가를 방문하여 하루 동안 진행되는 작업 단계별 작업인원, 상하차 비용 그리고 인건비 등을 각 지역별로 농협과 농가 총 40 곳을 대상으로 조사·분석하 였다.

Table 1. Storage duration, standard size of wire-steel pallet, weight of a bulk in a pallet, and onion vatieties used this study according to 5 packing house companies

\begin{tabular}{cccccc}
\hline Company & A & B & C & A & D \\
\hline $\begin{array}{c}\text { Storage period } \\
\text { (week) }\end{array}$ & 35 & 35 & 23 & 17 & 18 \\
Size (mm) & $1,200 \times 1,000 \times 950$ & $1,100 \times 1,100 \times 1,100$ & $1,600 \times 1,000 \times 1,300$ & $1,200 \times 1,000 \times 950$ & $1,200 \times 1,000 \times 950$ \\
$\begin{array}{c}\text { Weight of loaded amount } \\
\text { mean (kg)/ea pallet }\end{array}$ & 483 & 575 & 835 & 483 & 460 \\
Variety & Kataruru & New Mars & Sunpower & Power ball & Mandala \\
\hline
\end{tabular}




\section{결과 및 고찰}

벌크용 톤백과 와이어철제파렛트 개발

새로 개발한 수확용 톤백은 지게차를 이용하여 사방에서 삽입이 가능하며 로프를 이용하여 한번에 4 개 이상씩의 톤백을 이동 할 수 있게 하였다. 또한 기존 사용중인 톤백과 비교하기 위해 KOTITI시험연구원에 2015년 6월 18일에 의뢰하여 인장강도를 조사하였다. 그 결과 기존 톤백의 경 우 길이 방향으로 $1,800 \mathrm{~N}$ 그리고 폭 방향으로는 2,000 $\mathrm{N}$ 인장강도를 나타내었으며, 새로 개발한 톤백은 길이 방향 으로 $2,100 \mathrm{~N}$, 폭 방향으로는 $2,200 \mathrm{~N}$ 으로 인장강도가 더 높은 것으로 확인 되었다(Fig 3).

양파 저장시 압력이 가중되었을 때 와이어철제파렛트는 구조적 변형 가능성을 조사하기 위해 구조해석프로그램인 'ANSYS' 프로그램이 이용되었다. 'Young's Modulus(탄성

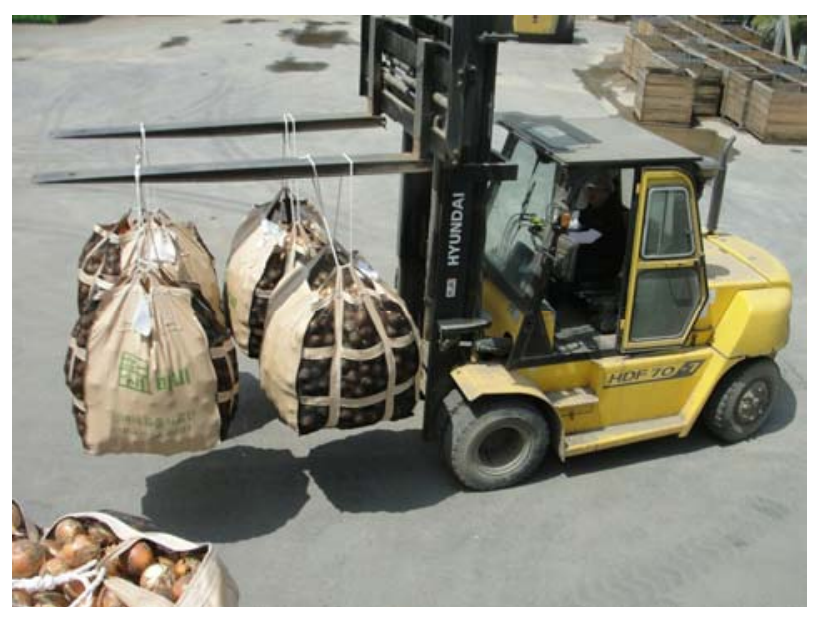

Fig. 3. Actual use the developed rope type ton bag during loading and carrying with forklift truck.
계수)'는 하중에 대하여 재료의 반응을 계산할 수 있으며, 인장에 작용하는 강선이 얼마나 늘어나는지, 또는 압축을 받는 기둥이 어떠한 하중 아래서 좌굴될 것인가를 예측할 수 있다(Fig 4).

항복강도는 탄성변형이 일어나는 한계응력을 말하는 것 으로 하중을 받아 탄성변형이 발생한 재료가 원상태로 복구 될 수 있는 한계점을 의미한다(6). 와이어철제파렛트 제작 하는데 사용한 철(SS400)의 항복응력은 $245 \mathrm{MPa}$ 이다. 개발 된 3 가지 종류의 와이어철제파렛트의 항복응력은 213.78 $\mathrm{MPa}, 243.23 \mathrm{MPa}$ 그리고 $106.12 \mathrm{MPa}$ 로 나타났으며 모두 기준이하로 설계되어 하중이 제거되면 변형된 철제파렛트 는 원상태로 복원된다는 것을 확인할 수 있었다. 총변형량 은 5단 적재할 경우 타입 I 은 3.42톤의 힘이 가해졌을 때 $1.4346 \mathrm{~mm}$ 변형 그리고 타입 ㅍ는 3.84톤 하중에 3.1608 $\mathrm{mm}$ 변형 가능성 있고, 타입 피는 4단 적재 할 경우 5.04톤 하중에 $0.8136 \mathrm{~mm}$ 변형되며, 압력이 제거되면 3종류의 철 제파렛트는 원상태로 복원된다(Table 2).

$165 \mathrm{~m}^{2}$ 저온저장고에서 저장 가능물량은 망 포장 후 기존 관행철제파렛트를 이용하면 약 201톤이었으나 와이어철제 파렛트는 약 220-240톤을 저장 할 수 있어 기존 관행철제파 렛트에 비해 약 $10 \%$ 정도 적재 효율이 높았다(Table 3).

한편 관행철제파렛트는 트럭적재에 따른 규격을 전혀 고려하지 않았기 때문에 5 톤 차량 기준으로 적재효율이 약 $45 \%$ 였으며 새로 개발된 와이어철제파렛트는 차량 적재 효율이 약 $85 \%$ 로 나타났다(7). 와이어철팔렛트의 장점은 사용하지 않을 경우 접어서 다단 적재해서 보관할 수 있어 보관 공간 확보에 보다 효율적이라 생각된다(Fig 5).

관행 그물망 저장과 와이어철제파렛트를 이용한 벌크저 장에 따른 감모율 비교

국내 대표적인 양파 저장업체인 경북의 $\mathrm{B}$ 업체에서 일반

Table 2. Standard and strengths for some tested stresses of 3 kind of the new developed wire-steel pallets. The raw material 'Iron SS400' used for making pallets had $245 \mathrm{MPa}$ of yield strength

\begin{tabular}{cccccc}
\hline Division & Size $(\mathrm{mm})$ & $\begin{array}{c}\text { Weight } \\
(\mathrm{kg})\end{array}$ & $\begin{array}{c}\text { Yield strength } \\
(\mathrm{MPa})\end{array}$ & $\begin{array}{c}\text { Total deformation } \\
(\mathrm{mm})\end{array}$ & Maximum load (ton) \\
\hline Type I & $1,200 \times 1,000 \times 950$ & 500 & 213.78 & 1.4346 & 3.42 \\
Type II & $1,100 \times 1,100 \times 1,100$ & 600 & 243.23 & 3.1608 & 3.84 \\
Type III & $1,600 \times 1,000 \times 1,300$ & 1,000 & 106.12 & 0.8136 & 5.04 \\
\hline
\end{tabular}

Table 3. The comparison of stored onion amounts in cold packinghouse between the developed wire-steel pallets and a practice pallet. Amount of stored onion is based on the volume of $165 \mathrm{~m}^{2}(13 \mathrm{~m} \times 11 \mathrm{~m})$

\begin{tabular}{ccccc}
\hline Division & Type I (A) & Type $\Pi$ (B) & Type III (C) & Practice pallet \\
\cline { 2 - 5 } & $1,200 \times 1,000 \times 950$ & $1,100 \times 1,100 \times 1,100$ & $1,600 \times 1,000 \times 1,300$ & $1,350 \times 1,200 \times 1,700$ \\
\hline Loading layers & 5 & 5 & 4 & 3 \\
Quantity (EA) & 440 & 400 & 288 & 168 \\
Weight of onions (kg/EA) & 500 & 560 & 850 & 1,200 \\
Total amount of onion (kg/volumn unit) & 220,000 & 224,000 & 244,800 & 201,600 \\
\hline
\end{tabular}



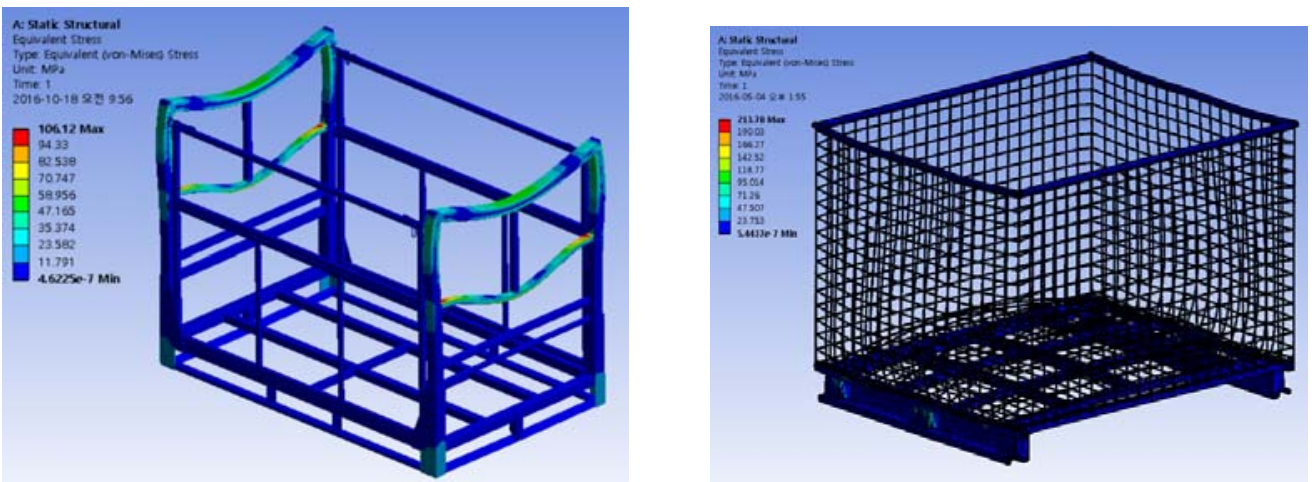

Fig. 4. The photographic of wire-steel pallet equivalent (von-mises) stress calculated with 'ANSYS' program.
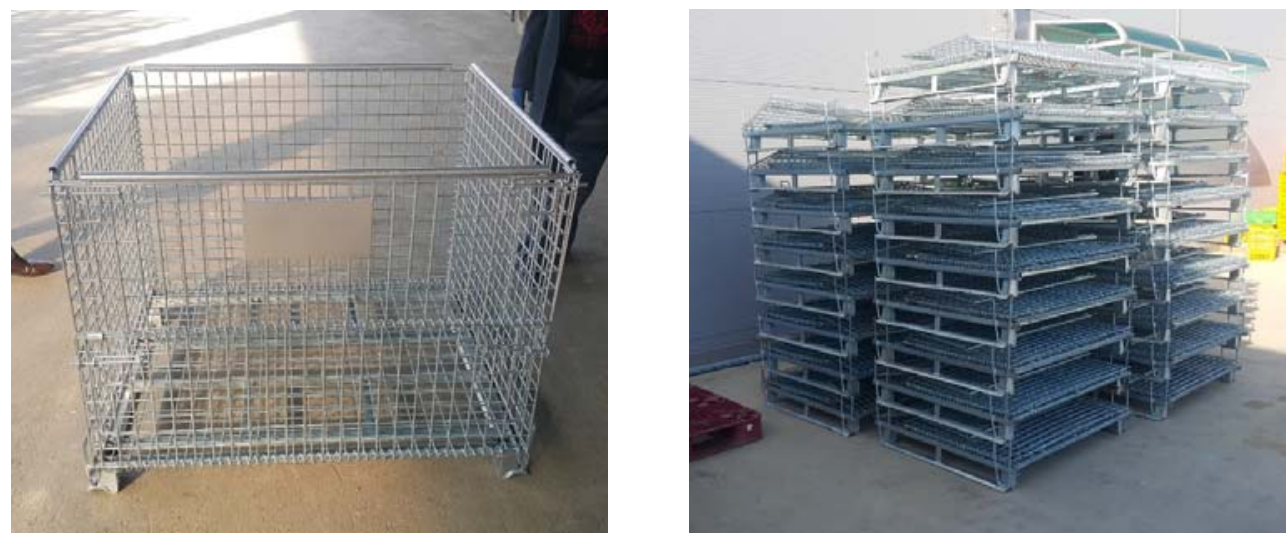

Fig. 5. The description of the developed wire-steel pallet assembled and hinged forms, respectively.

적인 양파 전용 그물망을 이용한 관행 저장과 개발된 와이 어철제파렛트를 이용한 벌크 저장시 8개월간 저장 전후를 비교한 모습은 Fig. 6과 같다. 관행 그물망 저장시 $12.1 \%$ 그리고 벌크 저장시 감모율은 $11.5 \%$ 로 감모율의 유의적 차이는 없었다. 이 결과는 한국농촌경제연구원에서 조사한 평균 양파 감모율 $16.1 \%$ 에 비해 낮은 감모율을 보였다(8). 양파 감모율은 재배환경, 품종, 저장 전처리 등에 따라 차이 가 있으며 저장업체별 자체기술이 다르기 때문이라고 사료 된다.
전남지역 대표적인 양파 저장업체인 A업체에서 2015년 과 2016년 두 해에 걸쳐 저장한 양파의 감모율을 조사한 결과 2015년산 양파의 8개월 저장 후 그물망 저장과 벌크 저장 후 감모율이 각각 $18.4 \%$ 와 $18.7 \%$ 이었다. 2016 년산 양파의 4 개월 저장 후 감모율은 관행 저장은 $4.9 \%$ 그리고 벌크 저장은 $4.7 \%$ 로 저장유형에 따른 감모율은 유의적 차 이가 없었다. 전북의 $\mathrm{D}$ 업체도 2016년도에 4 개월간 저온저 장 후 감모율 차이를 비교한 결과 관행과 벌크 저장시 $5.0 \%$ 와 $5.1 \%$ 로 유의적 차이가 없었다. 그러나 경남의 $\mathrm{C}$ 업체에
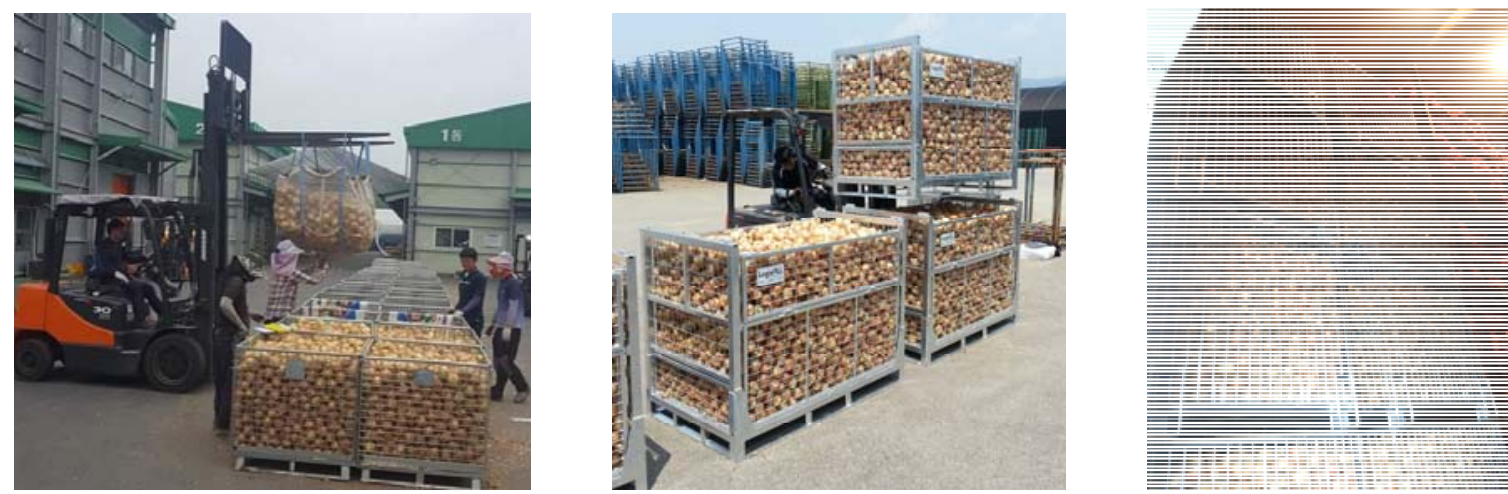

Fig. 6. Appearance and condition of bulk stored onion with the wire-steel pallet and layering of bulk in cold packing house. 
Table 4. The comparison of rates total weight losses between bulk used with the developed wire-steel pallets and practice used with the net for onion handling after storage at $0-0.5^{\circ} \mathrm{C}$ and $\mathrm{RH} 70-80 \%$

\begin{tabular}{cccccc}
\hline \multirow{2}{*}{ Division } & \multicolumn{2}{c}{2015} & & 2016 \\
\cline { 2 - 6 } & $\mathrm{A}$ & $\mathrm{B}$ & $\mathrm{C}$ & $\mathrm{A}$ & $\mathrm{D}$ \\
\hline $\begin{array}{c}\text { Storage Period } \\
\text { (week) }\end{array}$ & 35 & 35 & 23 & 17 & 18 \\
$\begin{array}{c}\text { Practice } \\
(\%)\end{array}$ & $18.4 \pm 0.8^{\mathrm{al})}$ & $12.1 \pm 0.5^{\mathrm{a}}$ & $15.6 \pm 1.4^{\mathrm{b}}$ & $4.9 \pm 0.4^{\mathrm{a}}$ & $5.0 \pm 0.2^{\mathrm{a}}$ \\
$\begin{array}{c}\text { Bulk } \\
(\%)\end{array}$ & $18.7 \pm 0.2^{\mathrm{a}}$ & $11.5 \pm 0.7^{\mathrm{a}}$ & $19.3 \pm 0.6^{\mathrm{a}}$ & $4.7 \pm 0.2^{\mathrm{a}}$ & $5.1 \pm 0.3^{\mathrm{a}}$ \\
& $\mathrm{NS}^{2)}$ & $\mathrm{NS}$ & $* *$ & $\mathrm{NS}$ & $\mathrm{NS}$ \\
\hline
\end{tabular}

${ }^{1)}$ Each value is mean $\pm \mathrm{SD}(\mathrm{n}=4)$

2)****,***,NS, significant at $\mathrm{p} \leq 0.05$, or at $\mathrm{p} \leq 0.01$, or at $\mathrm{p} \leq 0.001$, no Significant, respectively.

Table 5. The comparison of working hours between both of handling with the developed ton bag and with practice net for onion

\begin{tabular}{ccccc}
\hline Division & $\begin{array}{c}\text { Practice (A) } \\
(\mathrm{hr} / \mathrm{ha})\end{array}$ & $\begin{array}{c}\text { Bulk (B) } \\
(\mathrm{hr} / \mathrm{ha})\end{array}$ & $\begin{array}{c}\text { B/A } \\
(\%)\end{array}$ & $\begin{array}{c}\text { Saving Rate } \\
(\%)\end{array}$ \\
\hline harvesting & 412.5 & 234.0 & 56.7 & 43.3 \\
Load & 53.7 & 5.1 & 9.5 & 90.5 \\
Transport & 3.8 & 2.3 & 60.5 & 39.5 \\
Unload & 23.7 & 5.1 & 21.5 & 78.5 \\
Total & 493.7 & 246.5 & 49.9 & 51.1 \\
\hline
\end{tabular}

서 벌크 저장과 관행 저장의 평균 차이인 $3.7 \%$ 는 유의적인 차이가 있는 것으로 나타나 벌크저장의 감모율이 더 높은 것으로 조사되었다. 이는 기존 저온저장고의 냉기순환이 와이어철제파렛트의 내부까지 냉기가 제대로 전달되지 못 하여 부패 발생이 증가한 것으로 판단된다(Table 4). 따라서 양파를 $1,000 \mathrm{~kg}$ 이상의 많은 양을 한꺼번에 저장할 경우 기존 저온저장고에서 $1,000 \mathrm{~kg}$ 용량의 벌크 저장방식은 맞 지 않으며, 기존 저온저장고에 와이어철제파렛트를 이용해 양파를 저장할 경우는 저장물량이 $500 \mathrm{~kg}$ 내외의 용량이 적합하였다.

Table 6. Economic efficiency analysis of practices and bulk storage

\begin{tabular}{|c|c|c|c|c|c|}
\hline \multicolumn{2}{|c|}{ Division } & Practice (A) & Bulk (B) & $\mathrm{B} / \mathrm{A}$ & Saving Rate \\
\hline \multicolumn{2}{|c|}{ Crop yield (ton) } & 63 & 63 & & \\
\hline \multicolumn{2}{|c|}{ Purchase price (won) } & $8,862,210$ & $18,900,000$ & & \\
\hline \multicolumn{2}{|c|}{ Service life (year) } & 10 & 10 & & \\
\hline \multirow{4}{*}{$\begin{array}{l}\text { Annual fixed-cost } \\
\text { (won) }\end{array}$} & depreciation $\operatorname{cost}^{2}{ }^{2}$ & 886,221 & $1,890,000$ & 213.3 & \\
\hline & Repair cost ${ }^{33}$ & 17,724 & 37,800 & 213.3 & \\
\hline & Fixed capital cost ${ }^{4}$ & 221,555 & 472,500 & 213.3 & \\
\hline & Subtotal & 903,955 & $1,927,810$ & 213.3 & \\
\hline \multicolumn{2}{|c|}{ Fixed cost (won/ton) (1)) } & 17,865 & 38,100 & 213.3 & $210 \%$ \\
\hline \multirow{4}{*}{$\begin{array}{l}\text { Annual flow-cost } \\
\text { (won) }\end{array}$} & Labor cost ${ }^{5}$ & $5,373,203$ & $3,120,434$ & 58.1 & \\
\hline & Transport cost ${ }^{5}$ & $3,179,400$ & $1,348,469$ & 42.4 & \\
\hline & Material cost" & 642,000 & 483,750 & 75.4 & \\
\hline & Subtotal & $8,570,468$ & $4,507,003$ & 53.9 & \\
\hline \multicolumn{2}{|c|}{ Flow cost (won/ton) (2) } & 145,946 & 78,614 & 53.9 & $46.1 \%$ \\
\hline \multicolumn{2}{|c|}{ Total cost (won/ton) $(=(1)+2)$} & 163,811 & 116,714 & 71.2 & $28.8 \%$ \\
\hline
\end{tabular}

\footnotetext{
${ }^{1)}$ Practice pallet (49.23 ea/ha, 180,000 won/ea), Bulk pallet (126/ha, 150,000 won/ea).

${ }^{2)}$ Depreciation cost: 10 years.

${ }^{3)}$ Repair cost: Depreciation cost $\times 0.2 \%$.

${ }^{4)}$ Fixed capital cost: Purchase price $2 \times 5 \%$.

${ }^{5} 2016$ average price.
} 
관행 그물망 저장과 비교하여 톤백과 와이어철제파렛트 를 이용한 벌크저장에 따른 경제성 분석

양파 수확시 소요되는 노동투입 시간을 비교한 결과 그 물망 수확보다 톤백을 이용한 수확이 $50.1 \%$ 의 투입시간 절감 효과가 있는 것으로 분석되었다(Table 5). 상차 작업에 서는 관행망 수확은 밭에서 도로까지 꺼내기 작업이 필요하 지만 톤백 수확시 꺼내기 작업이 필요가 없기 때문이다. 특히 담기작업 이후 망 꺼내기 및 상차작업은 관행망 수확 시 53.7시간이 투입되는 반면 톤백을 이용하여 수확하면 5.1 시간만 투입되어 $90.5 \%$ 의 노동시간 절감 효과가 있었다. 또한 수확비용은 톤백 수확이 관행 망 수확 대비 $46.1 \%$ 의 투입비용을 절감시킬 수 있는 것으로 나타났다. 따라서 연 간 고정비와 연간 유동비를 모두 합한 총비용을 분석한 결과 양파의 수확(담기)에서 저온저장고 저장시까지 관행 망 저장은 톤당 163,811 원 그리고 벌크저장은 톤당 116,714 원의 비용이 투입됬다. 톤백을 이용한 수확 및 와이어철제 파렛트 벌크저장을 적용하면 기존 관행망 저장보다 $28.8 \%$ 의 비용을 절감할 수 있었다(Table 6). 기존 연구에서 벌크 철제파렛트 적용은 관행망 작업보다 투입비용을 $24.5 \%$ 절 감하는 것으로 보고되어 있다(9).

톤백 수확의 투입비용 추정에 따르면 관행망 수확 대비 톤백 수확 비중을 늘려갈수록 투입비용이 절감되는 것을 알 수 있다. 국내 양파 생산량의 벌크톤백 수확 비중을 연간 $30 \%$ 적용 시에는 관행망 수확보다 투입비용을 183 억 원 $(8.6 \%)$ 절감시킬 수 있는 것으로 분석되었다(Table 7).
길이방향 인장강도가 $16 \%$ 높았으며, 개발한 와이어철제파 렛트가 관행철제파렛트보다 약 $10 \%$ 더 저장가능하고 차량 적재 효율도 2 배 이상 향상되었다. 개발된 $500 \mathrm{~kg}$ 용 와이어 철제파렛트의 벌크저장과 관행 그물망 저장의 감모율에는 차이가 없었으나, $1,000 \mathrm{~kg}$ 이상 많은 양을 저장할 경우 와이어철제파렛트 벌크저장은 관행저장보다 감모율이 $3.7 \%$ 높아 적합하지 않는 것으로 나타났다. 톤백을 이용한 벌크 수확이 관행 망 수확보다 노동시간이 $50.1 \%$ 그리고 총 투입비용은 $46.1 \%$ 감소할 수 있는 것으로 나타났다. 와이어철제파렛트를 적용한 벌크저장이 관행저장보다 총 저장비용이 $28.8 \%$ 감소하였으며, 2016년 양파생산량 $(1,298,749$ 톤)의 $30 \%$ 를 와이어철제파렛트 벌크저장으로 대체할 경우 연간 183 억 원을 절감할 것으로 추정된다. 따라 서 현재 산지업체들의 와이어철제파렛트를 조기 도입하여 정착시키면 전국적으로 노동력 및 비용 절감에 상당한 효과 가 있을 것으로 판단된다.

\section{References}

1. RDA (2015) Agricultural Management Data (Onion). Rural Development Administration, Publication sequence number 11-1390000-003926-10, Jeonju, Korea, p 14-15

2. National Agricultural Cooperative Federation (2007) Post-harvest Management Technical Manual. Seoul, Kora, p 86

Table 7. Estimation of costs for bulk control at harvest and storage according to 5 simulation conditions compared to practice control of onion

\begin{tabular}{|c|c|c|c|c|c|c|c|c|}
\hline \multirow{2}{*}{\multicolumn{2}{|c|}{ Division }} & \multicolumn{2}{|c|}{ Harvest method } & \multicolumn{2}{|c|}{ Total cost } & \multirow{2}{*}{ Total } & \multirow{2}{*}{ Saving cost } & \multirow{2}{*}{ Saving Rate } \\
\hline & & Practice & Bulk & Practice & Bulk & & & \\
\hline \multicolumn{2}{|c|}{ Present } & $100 \%$ & - & $212,749,372$ & - & $212,749,372$ & - & - \\
\hline \multirow{5}{*}{ Simulation } & I & $90 \%$ & $10 \%$ & $191,474,435$ & $15,158,219$ & $206,632,654$ & $6,116,718$ & 2.9 \\
\hline & $\Pi$ & $80 \%$ & $20 \%$ & $170,199,498$ & $30,316,438$ & $200,515,936$ & $12,233,436$ & 5.8 \\
\hline & III & $70 \%$ & $30 \%$ & $148,924,561$ & $45,474,657$ & $194,399,218$ & $18,350,154$ & 8.6 \\
\hline & IV & $50 \%$ & $50 \%$ & $106,374,686$ & $75,791,095$ & $182,165,781$ & $30,583,591$ & 14.4 \\
\hline & $\mathrm{V}$ & $30 \%$ & $70 \%$ & $63,824,812$ & $106,107,534$ & $169,932,346$ & $42,817,026$ & 20.1 \\
\hline
\end{tabular}

\section{요 약}

양파의 관행 수확과 저장 방식을 개선하여 벌크 상태로 수확하여 수송, 하역, 보관 및 저장할 수 있도록 톤백 및 와이어철제파렛트를 개발한 후 관행저장 방식과 벌크저장 후 저장성을 비교하고 그에 따른 노동투입시간 및 소요비용 을 비교하여 양파의 산지물류비 절감 효과를 비교 분석하고 자 하였다. 본 연구를 통해 개발된 톤백이 관행 톤백보다
3. Statistics Korea (2014) Agricultural Production Cost Survey Report (onion production cost). Seoul, Korea, $p$ 80-85

4. Kim JH (2012) Onion garlic machining and multI- victory recycling are more expensive. Muan-newspaper. http://www.muannews.com/news/articleView. html? idxno= 194261 (accessed February 2016)

5. Cho JE, Bae RN, Lee SK (2010) Current research status 
of postharvest technology of onion (Allium cepa L.). Korean J Hort Sci Technol, 28, 522-527

6. Korea Standards Association (2016) Rolled structural steel KS D 3503

7. Korean Agency for Technology and Standards (2015) Pallet System Design Standard. Eumseong, Korea
8. Korea Rural Economic Institute (2016) Agricultural Observation Monthly Report (onion). Naju, Korea, March issue $\mathrm{p} 7$, October issue p 10, November issue p 10 9. Ministry of Agriculture, Food and Rural Affairs (2009) Development of a Postharvest Bulk Handling System for Onions. Sejong, Korea, p 95-96 